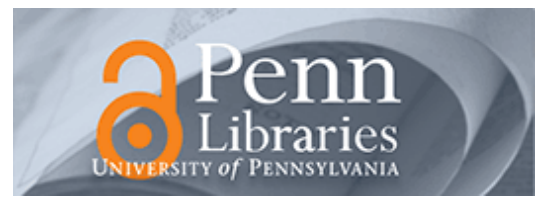

University of Pennsylvania

ScholarlyCommons

Marketing Papers

Wharton Faculty Research

2013

\title{
The Ombudsman: Is the Evidence Sufficient to Take Action on Executive Pay? Reply to Commentators
}

\author{
J. Scott Armstrong \\ University of Pennsylvania, armstrong@wharton.upenn.edu \\ Philippe Jacquart
}

Follow this and additional works at: https://repository.upenn.edu/marketing_papers

Part of the Business Administration, Management, and Operations Commons, Business and Corporate Communications Commons, Business Law, Public Responsibility, and Ethics Commons, Marketing Commons, and the Organizational Behavior and Theory Commons

\section{Recommended Citation}

Armstrong, J. S., \& Jacquart, P. (2013). The Ombudsman: Is the Evidence Sufficient to Take Action on Executive Pay? Reply to Commentators. Interfaces, 43 (6), 602-604. http://dx.doi.org/10.1287/ inte.2013.0710

This paper is posted at ScholarlyCommons. https://repository.upenn.edu/marketing_papers/349

For more information, please contact repository@pobox.upenn.edu. 


\title{
The Ombudsman: Is the Evidence Sufficient to Take Action on Executive Pay? Reply to Commentators
}

\author{
Abstract \\ The experimental evidence in this collection of papers is sufficient for organizations to take action-at \\ least with respect to investigating or testing alternative pay schemes. Some organizations have already \\ implemented a number of these procedures. The failure of an organization's directors to follow evidence- \\ based procedures for executive pay might be used as a basis for legal action by shareholders when \\ results are detrimental to a firm.

\section{Keywords} \\ corporate governance, executive compensation, incentives, Mondragon, say on pay

\section{Disciplines} \\ Business | Business Administration, Management, and Operations | Business and Corporate \\ Communications | Business Law, Public Responsibility, and Ethics | Marketing | Organizational Behavior \\ and Theory
}




\title{
Is the Evidence Sufficient to Take Action on Executive Pay? Reply to Commentators
}

\author{
Philippe Jacquart \\ EMLYON Business School \\ Ecully, France \\ jacquart@em-lyon.com \\ J. Scott Armstrong \\ The Wharton School \\ University of Pennsylvania \\ Philadelphia, Pennsylvania \\ Adjunct Researcher \\ Ehrenberg-Bass Institute \\ University of South Australia \\ Adelaide, South Australia \\ armstrong@,wharton.upenn.edu
}

Published in final edited form as:

Armstrong, J. S., \& Jacquart, P. 2013. The Ombudsman: Is the Evidence Sufficient to Take Action on Executive Pay? Reply to Commentators. Interfaces, 43(6): 602-604. 


\begin{abstract}
The experimental evidence in this collection of papers is sufficient for organizations to take action - at least with respect to investigating or testing alternative pay schemes. Some organizations have already implemented a number of these procedures. The failure of an organization's directors to follow evidence-based procedures for executive pay might be used as a basis for legal action by shareholders when results are detrimental to a firm.
\end{abstract}

Keywords: corporate governance; executive compensation; incentives; Mondragon; say-on-pay. 
With the exception of Christopher Armstrong, the commentaries are largely sympathetic to the conclusions in Jacquart and Armstrong (2013). The difference arises primarily because Armstrong (2013) focused on non-experimental findings, an issue that we examine in our main paper. He also questioned the feasibility of conducting realistic experiments.

\section{Can one generalize from experimental findings about pay practices?}

Experimental findings have been challenged in many important areas. The primary objection is that the findings, especially from laboratory experiments, lack realism. Locke (1986) addressed the generalizability of laboratory experiments by asking researchers in 11 areas of human and organizational behavior to compare the findings from laboratory experiments with those from field experiments. The findings from each approach showed much agreement. Economists have also made the case for the generalizability of experiments (Camerer 2011; Falk and Heckman 2012).

The standard approach for assessing decision-making in realistic conditions is to use roleplaying (e.g., "you are the CEO of company X and you face the following situation"). Armstrong (2001) provides a description of how to use role-playing for prediction, along with evidence on its predictive validity. For example, Green (2005) found that college students made similar decisions to those in eight actual (disguised) situations when asked to play the role of top executives.

Natural experiments can provide useful evidence such as through changes in government regulations. For example, in an effort to strengthen the contractual right of owners, the 2010 Dodd-Frank regulation includes a provision that firms' owners be given the right to cast a "nonbinding" advisory vote at least once every three years on whether to approve the compensation 
of the five highest-paid executives, the so-called "say-on-pay" (SOP) provision. In the first two years, firms using SOP had lower CEO compensation and better financial performance than firms not using SOP (Kimbro and Xu 2013).

\section{How should performance be assessed?}

Christopher Armstrong raises the issue of how to assess performance. He presents evidence that executive compensation — in terms of overall wealth rather than annual pay — is related to firms' performance. In contrast, Hogarth and Kolev (2013) suggest that attention should be given to how current pay affects future performance. Answering this question with nonexperimental data, they found that total compensation was negatively correlated to future performance.

We conclude that outcomes should not be used as a measure of performance. Indeed, using them as such is likely to be harmful. For example, many companies use market-share as a performance measure although it is inconsistent with the belief that firms should maximize profits. Experimental evidence has shown that competitor-oriented objectives like market-share are harmful (Armstrong and Green 2007).

Performance incentives harm performance (Deci and Ryan 2013). They also harm learning in firms where knowledge and skills are important (Seijts and Latham 2005). Deci and Ryan (2013) suggests a solution: focus on behaviors, rather than financial performance. Such an approach is used, for example, to assess the performance of medical doctors. When things go badly, doctors are likely to be sued for failing to use evidence-based procedures.

Few top executives rely on evidence-based methods. Consider the ability to plan, an important skill for top executives. Although evidence-based procedures for corporate planning are available (Armstrong 1982a), few executives use this knowledge (Armstrong and Reibstein 
1985). In particular, executives often fail to use proper procedures for setting objectives. Locke and Latham (2002) describe how to properly set objectives, using findings from decades of research.

Rather than following evidence-based procedures, Jack Welch, former Chairman and CEO of General Electric, advised executives to go with their gut feelings when making important decisions. His approach seems to have been met with much agreement. Now imagine a medical doctor trying to defend a poor decision because if felt good.

\section{Should Firms Take Action on the Recommendations?}

As Jones (2013) notes, many industrial economists have analyzed the Mondragon experience. Firms adopting these solutions have been more successful than those using traditional executive pay practices for well over half a century. Those needing more evidence should commission experiments that could be done at a fraction of the cost of selecting a single CEO.

Organizations can change their pay procedures by first asking key people if they would be willing to consider changes in any aspects of the executive payment plan. If not, there is no use to proceed. If yes, work with them to (1) identify the possible areas for change, (2) develop alternative procedures, (3) describe the evidence necessary for change and (4) obtain the evidence. Armstrong (1982b) summarizes evidence related to this approach.

\section{Conclusions}

As with medicine, experimental studies provide the gold standard for studying problems in complex, uncertain areas. Much has been learned about the expected effects of payment schemes from experiments to date. 
Organizations in a variety of industries and countries have successfully applied these solutions for decades. Given the evidence, we expect more organizations will do so in the future. When things go poorly, Pfeffer (2013) suggests that organizations apply sanctions when top executives fail to follow evidence-based procedures. For example, shareholders could file lawsuits against executives who are unable to demonstrate that they followed proper procedures and merely went with their gut.

\section{Online Supplement}

An online supplement to this paper is available as part of the online version that can be found at http://dx.doi.org/10.1287/inte.2013.0705

\section{Acknowledgments}

We thank Kesten C. Green for his useful suggestions on an earlier draft. Jennifer Kwok, Jennifer Shulkin, Katherine Wang and Alice Mack edited the paper. 


\section{References}

Armstrong CS (2013) A closer look at the efficiency of top executive pay and incentives. Interfaces 43(6):590-592.

Armstrong JS (1982a) The value of formal planning for strategic decisions: Review of empirical research. Strategic Management J. 3(3):197-211.

Armstrong JS (1982b) Strategies for implementing change: An experiential approach. Group Organ. Stud. 7(4):457-475.

Armstrong JS (2001) Role playing: A method to forecast decisions. In Principles of Forecasting (Kluwer Academic Publishers, Boston), 15-32.

Armstrong JS, Green KC (2007) Competitor-oriented objectives: The myth of market share. Internat. J. Bus. 12(1):117-136.

Armstrong JS, Reibstein DJ (1985) Evidence on the value of strategic planning in marketing: How much planning should a marketing planner plan? Thomas H, Gardner D, eds. Strategic Marketing and Management (John Wiley \& Sons, New York), 73-87.

Camerer, CF (2011). The promise and success of lab-field generalizability in experimental economics: a critical reply to Levitt and List (December 30, 2011) Available at SSRN: http://ssrn.com/abstract $=1977749$

Deci EL, Ryan RM (2013) Do CEOs' aspirations for wealth harm stockholders? Interfaces 43(6):593-595.

Falk, A., \& Heckman, J. J. (2009). Lab Experiments Are a Major Source of Knowledge in the Social Sciences. science, 326: 535-538.

Green KC (2005) Game theory, simulated interaction, and unaided judgment for forecasting decisions in conflicts: Further evidence. Internat. J. Forecasting 21(3):463-472. 
Hogarth RM, Kolev GI (2013). The “wicked” environment of CEO pay. Interfaces 43(6):596598.

Jacquart P, Armstrong JS (2013) Are top executives paid enough? An evidence-based review. Interfaces 43(6):580-589.

Jones DC (2013) Employee ownership as a mechanism to enhance corporate governance and moderate executive pay levels. Interfaces 43(6):599-601.

Kimbro MB, Xu D (2013) Shareholders have a say on executive compensation: Evidence from say-on-pay in the United States. (April 1, 2013). Available at SSRN: http://ssrn.com/abstract=2209936 or http://dx.doi.org/10.2139/ssrn.2209936.

Locke EA (1986) Generalizing from Laboratory to Field Settings (Lexington Books, Lexington, MA).

Locke EA, Latham G (2002) Building a practically useful theory of goal setting and task motivation: A 35-year odyssey. Amer. Psych. 57(9):705-717.

Pfeffer J (2013) Evidence and executive compensation—like trains passing in the night? Interfaces 43(6):578-579.

Seijts GH, Latham G (2005) Learning versus performance goals: When should each be used? Acad. Management Executive 19(1):124-131. 